\title{
The Role of Empowering Village Managers in Tourism Industry: A Case Study of Bojnord Villages
}

\author{
Hamid Jafari \\ PhD in Rural Planning, Department of Geography, Islamic Azad University of Mashhad, \\ Mashhad, Iran
}

Mona Afrassiabi

PhD scholar in Rural Planning, Department of Geography, Islamic Azad University of Mashhad, Mashhad, Iran Email: mona.afrasiabi_dr@yahoo.com

DOI: $\quad 10.6007 /$ IJARBSS/v3-i8/173 URL: http://dx.doi.org/10.6007/IJARBSS/v3-i8/173

\begin{abstract}
The present study entitled 'The Role of Empowering Village Managers in Tourism Industry: A Case Study of Bojnord Villages' aimed at investigating and analyzing the village managers and councils' performance. The main question to be scrutinized was "Does empowering village managers play an effective role in developing tourism industry?" To answer the question, the following hypothesis was formulated: "Empowering village managers is essential in developing tourism industry." The instrument was a questionnaire whose validity was determined through Delphi and whose reliability through Chronbach's Alpha. The population of the study was composed of rural people of Bojnord chosen from 223 villages with an entire population of 158,665 people. The sampling method was multi-cluster sampling. These villages were chosen from among those that enjoyed tourist attractions and empowering village managers which could potentially gain benefits from the results of the present study. Thus the two axes of tourism including 20 villages with a population of 21,516 people were chosen as the sample population from which the subjects of the study were randomly selected. To determine the sample population, the researcher applied Morgan scale where 52 rural managers were sampled out to take the questionnaires. Having been collected and processed, the data were analyzed through SPSS and Spearman Ranking Correlations. The results revealed that there was a significant relationship between empowering village managers and tourism industry development. Based on the results, the most important problems of the managers in tourism industry development were their lack of knowledge, financial resource deficiency, and the absence of new technology. To solve the problems requires the manager cooperation and government's support in all the grounds of development.
\end{abstract}

Key words: empowering, village manager, tourism development, rural tourism, Bojnord City 


\section{Introduction}

Villages as the smallest organizational and social units in Iran, with regard to the social and economic interactions and also people's commitment to the civil and common laws/rules, cannot be void of management organizations. Management organizations are basically influenced by the dominant social systems in human societies, and if this society is categorized under a higher and broader society, then the role of the higher society will also be significant (Moteie Langroudi, 2003: 229\& 230).

Studying the rural changes in pre-constitutional period shows that rural changes were affected by the conditions of managing the whole country and based upon the common laws/rules resulting from the cultural, religious, political and social conditions. Up until the time the first indications of new administration in Iran sprang up, it was the will and requirements of the owner that determined the relationships and changes in rural and inter-villages environment and in civil areas. Except for some specific instances, the central government played the least role in improving the conditions of rural people (Emadi and Darban Astaneh, 2005: 4).

In this time, rural management tackled its public affairs in a traditional way, in which the village manager played the major role; since, on one hand, he belonged to the common people, and the other hand, he was appointed by the owners; however, gradually, with the formations of "civil association of villages" in 1955 and "the associations of the villages" in 1956, rural management entered a new phase. Rural managers using village manager as the administrative power applied their rural development politics (Vadiee, 2005: 185).

After the Islamic Revolution, the Islamic Council of villages was responsible for the rural management. Even though the Islamic Council has replaced the Association of the village, it continued to work for 20 years with no administrative power. With the passage of the law of Rural Management Formation in 1998, rural management as the administrative power for the Islamic Council of the village was now at the front (Badri et al, 2010: 79 ).

Councils are assigned to urge villagers to trust each other and to reduce individual vulnerability. Councils support the villagers when facing outside-of-the-village societies. They also convey the villagers' messages to government units and they try to promote the villagers self-reliance. They ask them to actively participate in the economic development (including recognizing problems, giving solutions and supports); furthermore, since councils are the outcome of common peoples' elections, they ask people to take part in the council's annual elections actively and monitor the village councils' performance and prevent it from deviation (Kay, 1992: 57).

Islamic councils of villages which were founded in 1999 by the order of the Constitution of the Islamic Republic of Iran in more than 33857 villages in is an institution benefiting from a background of at least 5 four-year periods after the revolution, two of which were from 1982 to 1989 and the others have been active since 1999. They also have the experience of being actively in operation before the revolution and under the title of the Associations of Villages from 1964 to 1978 (Estelaji, 2012: 252).

Rural management as a public and non-governmental institution for the tackling of rural management affairs was practically born after the passage of the laws of formation, duties and elections of the country's Islamic councils and electing mayors, dated 1996 (known as the councils laws ) and the article of the law of the dependent rural management formation in the 
country's villages. Initially, rural managements began to work in more than 20000 qualified villages, and they provided about $17000 / 000$ people of the rural population with $76 \%$ of the total rural qualified population with civil and other services (Deputy of rural management affairs, 1998: 5). By the end of 2011, 659 licenses were issued for the rural managements of north Khorasan Province (Municipalities and Rural Managements Organizations of Iran, 2013). The existence of appropriate official structures, which could mean granting government supports, providing financial and bureaucratic facilities can guarantee the survival of rural managements. Rural managements in bigger villages have had a far more successful performance than the smaller ones, and the more the participation, the greater the achievement of rural management ( Nemati and Badri, 2007: 174 ). Among the strategic programs of tourism industry for which the rural manager is responsible are constructing and promoting entertainment and resort areas (parks and amusement parks ), green spaces, improving natural attractions, providing hygienic and suitable running water, promoting the skeletal texture of village, and the quality of sights to avoid visual distracters, improving the relationships between tourist organization and forming a single unified management to perform the tourism industry programs, promoting the transport system, providing tourist kiosks ( ask- me stands) and increasing the road signs directing tourists toward tourist attractions (Ebrahimzadeh et al, 2011: 137 ).

It should be mentioned that development programmers consider tourism activities as the pivotal part in permanent development. Nowadays rural tourism can result in job opportunities, increase in income and ultimately people's welfare. Dynamic rural economics through different kinds of economic factors is necessary (Moteie Langroudi, 2003: 81). When national or international conditions cannot pave the way for the development and expansion of international tourism, domestic development especially in deprived and less-developed regions can play a significant role in the development of these regions (Jomepour, 2008: 87). Since tourism can lead to economic boom and variety in economic activities, job opportunities and increase in income for the villagers, this had been focused on by international societies, with regard to the local and regional development (Moteie Langroudi \& Nosrati, 2011: 70) and in as much as the fact that the higher effectiveness of this issue is dependent on its management, the present study has focused on the role of rural management in tourism industry.

\section{The Principles and Research Background}

At the age of the globalization of communications and centralization of capitals, programming for the sake of rural and local regions can prevent autocracy and individualism. New management of rural development should be equipped with understanding local development, initiatives and innovations, pluralism and participation to be capable of analyzing economic, social and environmental problems of rural atmospheres (Moteie Langroudi, 2003: 229\& 230). Rural participation can mean redistribution of economic and political power in favor of the deprived people. This redistribution is achieved through participation in economic power and increase in access to production facilities. It should also be added that participation in the social-political power which means taking part in decision-makings is voluntary (Alqanami, 1993: 60). 
Social issues and those related to rural management are rooted in common law, customs and traditions. Social behaviors are determined in the context of the necessities and requirements of that society and it is the social context which has determined the way its people achieve welfare (Taleb, 1997: 1). During the recent decades, rural development in Iran from a general perspective, and rural management from a specific perspective, have not benefited from a wellplanned and organized process (Saeedi et al, 1991: 4). It seems that the existence of a despotic institution is necessary to bring about order, cooperation and contribution among the various organizations in villages (Abdollahian et al, 2006: 234). Hence, getting promoted from a village to a town is not the problem with our villages; they want to be provided with facilities (Research Department of Jahad Daneshgahi, Tehran Branch, 2008: 52).

Forming some uniform formations for the nationwide management and determining the borders and limitations and duties at the national, regional and local levels are some of the factors preventing double or parallel jobs and pave the way for a better cooperation with other related parts (Rezvani, 2004: 238).

The rural management system of Iran has experienced some complicated changes for a long time, from the perspective of social structures. Although some institutions variously named as the Islamic Council, the House of Companion, the Rural Civil Office ... have been formed after the Islamic Revolution, they have always kept a low profile due to the lack of prerequisites and the related administrative organizations ( Mahdavi, 2005: 229 ).

Based on the law of "Formation of independent rural managements" in all the villages of Iran which was passed in 1998, by following the model of civil management consisting of two institutions of city council and municipality, Interior Ministry was allowed to form an organization named rural management, so as to be able to manage the rural affairs and permanent rural development. This institution was founded with regard to the local features, the request made by the local residents, independent management with an independent legal identity, in villages housing more than 20 families; various duties and expectations were assigned for this institution in one article and 48 paragraphs (Interior Ministry, 2003: 10).

The formation of rural management in villages can be considered as a turning point in the history of rural management (Khabbazzadeh, 2011: 6). Rural councils, as the qualified trustees who have some specific characteristics, can be decent managers to tackle the rural development programs which are based on people's participation and they can play a significant role in planning and programming rural development through getting the necessary training under the light of instructive policies. Since initially programming does need information on shortage, potentialities, the ways of determining and dedicating resources and reliable and the most recent information, the role of rural councils, with their knowledge on their village's problems, needs and to some extent their potentialities and present facilities is considerable (Khoushehgeer, 2003: 72).

The history of research in the field of tourism as a scientific field goes back to approximately 200 years ago. The first book on tourism entitled "Tourism Guide" was written by Thomas Nognet about 200 years ago. Since then, the studies carried out in this field can be categorized under 3 main groups; The first group deals with knowing and introducing tourist attractions, the second one engages in tourism and its effects and the last one concerns professional and specific studies on minor tourism fields (Shamaee and Mousavand, 2011: 26). The literature of the present study can be analyzed in the following items purposefully and carefully. 
In a study that Henning carried out in the rural area of Louisiana, it was concluded that tourists' frequent visits had had some considerably positive effects on the big rural areas. It was also determined that in most rural areas some local and regional markets had been formed which dealt with introducing types of local and ethnic items. He is also on the belief that rural tourism is an important factor for the development of less-developed and deprived rural regions, especially those benefiting from a limited possibility for development; they can consider tourism as the elixir of advancement and progress. Hence tourism can be a significant part of the management and development programs of a village (Henning, 1996: 68).

Bontor and Lasnier who did research in this field showed that the effects of local tourism at rural areas are dependent on factors like workforce structure and the issues and problems related to different seasons of the year. Their study also showed that local and regional managerial supports are an integral part and key to success in rural areas (Bontor and Lasnier, 1997: 95).

In their studies, Bourke, Brass, Woods and Burr drew the conclusion that the strategy of rural tourism should be in perfect harmony with the local goals, manners, customs, and culture of the region. It should also be in line with local rules and laws (Woods, 1992: 22; Burr, 1995: 47; Brass, 1996: 102; Bourke, 1995: 87).

The result that Weaver came to in his study was that rural tourism can increase not only job opportunities but also potential income; it can improve and strengthen local economy and can also be a tax resource for the management of rural areas. In addition, it can increase cultural opportunities for local residents (Weaver, 1986: 201).

Jurowski states that if well planned and managed, rural tourism can maintain or increase local environmental resources. He also discusses that rural tourism creates more job opportunities for the villagers and leads to variety in jobs. For instance, local and ethnic markets and increase in seasonal activities are some outcomes which create valuable job opportunities for the residents all year round (Jurowski, 1996:55).

Javan and Saqaee in their article entitled "The Role of Rural Tourism in Regional Development, Focusing on Rural Management" found out that rural tourism under the light of regional programming based upon rural tourism zoning and with regard to the economic, socio-cultural and environmental strategies can play a significant role in an encompassing development of village and from a broader perspective it can be a pivotal factor in regional development. At the moment, due to some problems like the decrease in profit of agricultural activities and also environmental pollution, in most countries rural tourism can be an acceptable alternative since it has brought about a set of economic activities and services and is the key to many other economic issues. This can be realized, provided that rural tourism is managed by some desirable rural management so as to pave the way for permanent rural tourism (Javan and Saqaee, 2004: 124).

Qadiri Massoum and Riahi in the article "Studying the Policies and Challenges of Rural Management in Iran" found that undoubtedly the most important measure to be taken by the Islamic Republic of Iran's programmers and ministries and organizations is the transition of rural management from the government to the villagers. As far as the transition of owning and managing the rural residencies are considered, the programming procedures and applying them are assigned to the rural council (Qadiri Massoum and Riahi: 1994, 193) 
Mohammadzadeh Larijani and Qorbani in their study "Studying the Challenges of Rural Management Structures in Iran" concluded that the background of rural management in Iran can be divided into two separate parts: the first part covers a time-period ending in "Land Reforms" in which the owner was the manager; from an impartial perspective, its performance was rather acceptable. But in the second part which was after the "Land Reforms", the engagement of the government in rural affairs which is state management can be seen. This type of management has always had problems. To overcome the problematic status quo and to enter a new and well-planned realm, it is necessary to pay attention to the past experiences in the fields of management, administration, planning, reforming the centralized system of programming and decision-making. There should be a logical and systematic relationship between all those engaged in the rural development in Iran (Mohammadzadeh Larijani and Qorbani, 2011: 16).

In an article entitled "Studying Rural Management in Iran", Khabbazzadeh found that founding rural managements, along with rural councils as the law-makers of the rural affairs, had empowered rural managers to control the administrative and practical affairs of the village. It is quite obvious that the present model of rural management is directly derived from the present civil management structure in which there are the two institutions of city council and municipality (Khabbazzadeh, 2011: 6)

In a case study, Taqavi dealt with "Studying the Stance of Tourism Industry in the Belad Shapour of Behdasht" and drew the conclusion that "though this region benefits from plenty of economic, socio-cultural and environmental potentialities, tourism has not played a considerable role in this region" ( Taqavi, 2006: 182)

Lee's comment on the economic effects of tourism is that tourism results in national income and National Gross Production. He also adds that tourism is an income resource for the government and believes that this industry results in improvement in social services (Lee, 1999: 54-55).

In his studying "The Effects of Rural Tourism Development on Creating Job Opportunities in Oramanat Region", Miezaee concluded that with regard to the active population and the young human resources, plenty of job opportunities have been generated directly or indirectly under the support of the government sector in tourism and also the investments of the private sector, which is really beneficial. Hence this research's findings show the development of rural tourism industry and increase in job opportunities in Oramanat region (Miezaee, 2009: 73-74).

"Studying Rural Management in Iran, with Focusing on the Role of Councils and Rural Managements" is the title of the study carried out by Malekan and Karimi, in which they found that the future of new rural management will rely on the capacities of local societies with exact managing and controlling of place and productivity of resources. The rural manager should take the understanding of local development, innovations, pluralism and participation into account and should be capable of understanding and analyzing the social, economic and environmental problems of the village. One of the ways to increase the technical capabilities of local management is founding local councils, and making a structure which has an active interaction with other institutions including rural managements; using their power of consultation and supervising, rural managers can make local managers be more responsible; in this way, they can practically exercise the decisions made by rural managers (Malekan and Karimi, 2011: 11). 
By having a bird's view on the above sources, it is obvious that the discussed advantages can be obtained, providing there is an efficient management. At best, this can eliminate all the rural problems or at least it can reduce the problems drastically.

\section{The hypothesis of the study}

Empowering managers is essential for the development of tourism.

The analytical model of this study is as follows.

Figure 1: The analytical model of the study

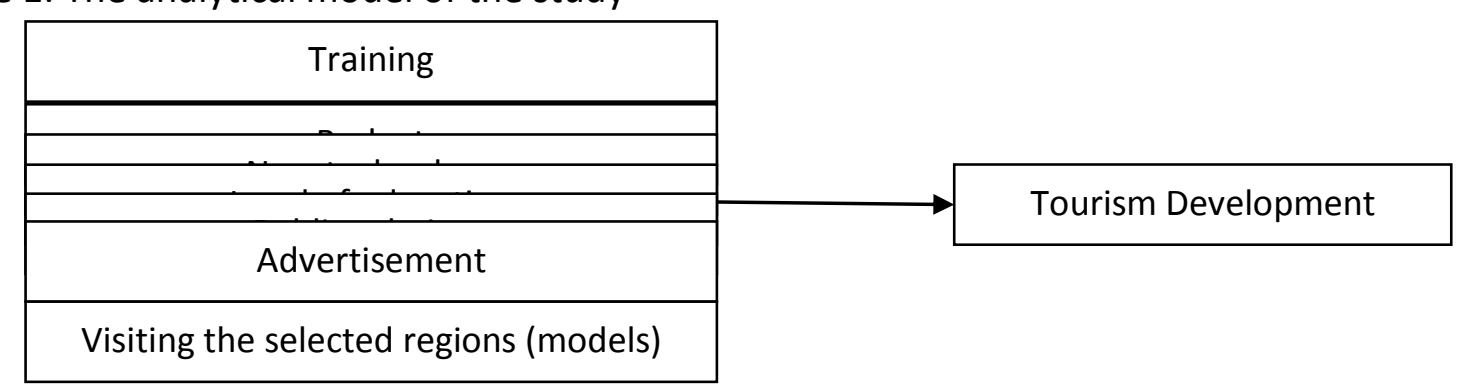

\section{Methodology}

The present study is descriptive-analytical, from the perspective of applied and practical purpose and its nature and method. In this study, the dependent variable is tourism development; the independent variable is empowering the managers, and the control variable is gender, and the moderate variable includes the organizational position of those engaged like the Islamic Council members or rural managers, age and level of education. In this study the population was composed of 223 villages with a population of 158665 people which needed sampling, due to the large number and vastness of the region. Hence the multi-cluster sampling was used at the first stage of which some villages were sampled out which had the characteristics of tourism and had village managers, and two tourist areas holding 20 villages with a population of 21516 were chosen as the sample society, and in the next stage people were chosen, using the random sampling method. To determine the sample volume, the statistical method and Krejcie and Morgan table were used. According to this table, from among 60 village managers in the region, 52 were selected as the sample; the data gathering method was not the field method which included library studies, i.e, books, articles, magazines and regional, national and international conferences and theses and dissertations and the related articles, internet, figures and statistics of the related organizations and offices and also the available maps; in the field method, for managers the questionnaires using the answer giving method of Likert were used.

To evaluate the validity of the questionnaires used in this study, based of Delphi method, experts and specialists were asked for their opinions and after the scrutinizing of the questionnaires by some experts and university professors, the validity of them was approved: Chronbach's alpha was used to evaluate the reliability of the questionnaires, the validity of which was also approved with the quotient of $79 \%$.

Statistical description (analysis), along with the descriptive figures and charts has been applied in analyzing the data of the present study, and the appropriate test of Spearman's rated data 
has been used in choosing the statistical test (non parametric equivalent of Pierson's correlation quotient), in SPSS.

\section{The range of the study}

The studied range covers the villages located in the city of Bojnourd, for the sampling of which the map of the city and the tourist-oriented map where combined and two major directions were studied. In the first direction were the eastern villages of Bojnord, the intersection of Asian Highway toward Mashhad with the minor road of Hamid village toward Esfidan. The second direction covered the villages in the west of Bojnord, the old road of Badranlou toward Tehran which are illustrated in the table 1.

Table 1: The Studied Tourist Direction

\begin{tabular}{|l|l|}
\hline Direction 1 & $\begin{array}{l}\text { Includes the villages: Baba Aman, Hamid, Chahar Kharvar, Kohkamar, Peighoo, } \\
\text { Chenaran, Jamei, Noudeh, Esfidan }\end{array}$ \\
\hline Direction 2 & $\begin{array}{l}\text { Includes the villages: Bidak, Qorreh nodeh, Teimour Tash, Goli, Sheikh Teimour, } \\
\text { Toot, Badranlou, Memeljeh, Nargeslou Sofla, Nargeslou Olya, Dehgah }\end{array}$ \\
\hline
\end{tabular}

\section{The Findings of the Study}

With regard to the purpose of the present study which is studying the significant relationship between the empowering of managers and tourism development in the city of Bojnord, based on the hypothesis of the study, the existence of the significant relationship will be dealt with, through Spearman's Correlation analysis.

Table 2: Correlation Quotient between the Managers' Empowering and Tourism Development from the perspective of Village Managers

\begin{tabular}{|c|c|c|c|c|c|c|c|c|c|}
\hline $\begin{array}{c}\text { Variabl } \\
\mathrm{e}\end{array}$ & $\begin{array}{l}\text { Statistical } \\
\text { figures }\end{array}$ & $\begin{array}{c}\text { Trainin } \\
\mathrm{g}\end{array}$ & $\begin{array}{c}\text { Budge } \\
t\end{array}$ & $\begin{array}{c}\text { New } \\
\text { technol } \\
\text { ogy }\end{array}$ & $\begin{array}{c}\text { Level of } \\
\text { educati } \\
\text { on }\end{array}$ & $\begin{array}{c}\text { Public } \\
\text { relatio } \\
\text { ns }\end{array}$ & $\begin{array}{c}\text { Advert } \\
\text { iseme } \\
\text { nt }\end{array}$ & $\begin{array}{l}\text { Visitin } \\
\text { g the } \\
\text { select } \\
\text { ed } \\
\text { region } \\
\text { s }\end{array}$ & $\begin{array}{c}\text { Touris } \\
\text { m } \\
\text { Devel } \\
\text { opme } \\
\text { nt }\end{array}$ \\
\hline \multirow[t]{3}{*}{$\begin{array}{c}\text { Trainin } \\
\mathrm{g}\end{array}$} & $\begin{array}{l}\text { Correlation } \\
\text { Coefficient }\end{array}$ & 1.000 & $0.701^{*}$ & $0.697^{* *}$ & $0.331^{*}$ & $0.858^{*}$ & $\underset{*}{0.817^{*}}$ & $0.300^{*}$ & $\underset{* *}{0.914}$ \\
\hline & $\begin{array}{l}\text { Sig.(2- } \\
\text { tailed) }\end{array}$ & . & 0.000 & 0.000 & 0.017 & 0.000 & 0.000 & 0.031 & 0.000 \\
\hline & Number & 52 & 52 & 52 & 52 & 52 & 52 & 52 & 52 \\
\hline Budget & $\begin{array}{l}\text { Correlation } \\
\text { Coefficient }\end{array}$ & $0.701^{*}$ & 1.000 & $0.392^{* *}$ & 0.068 & $\underset{*}{0.459^{*}}$ & $0.790^{*}$ & $\underset{*}{0.408^{*}}$ & 0.692 \\
\hline
\end{tabular}




\begin{tabular}{|c|c|c|c|c|c|c|c|c|c|}
\hline & $\begin{array}{l}\text { Sig.(2- } \\
\text { tailed) }\end{array}$ & 0.000 & • & 0.004 & 0.633 & 0.001 & 0.000 & 0.003 & 0.000 \\
\hline & Number & 52 & 52 & 52 & 52 & 52 & 52 & 52 & 52 \\
\hline \multirow{3}{*}{$\begin{array}{c}\text { New } \\
\text { techno } \\
\text { logy }\end{array}$} & $\begin{array}{l}\text { Correlation } \\
\text { Coefficient }\end{array}$ & $\underset{*}{0.697^{*}}$ & $0.392^{*}$ & 1.000 & $0.492^{* *}$ & $0.771^{*}$ & $\begin{array}{c}0.737^{*} \\
*\end{array}$ & 0.184 & $\underset{* *}{0.772}$ \\
\hline & $\begin{array}{l}\text { Sig.(2- } \\
\text { tailed) }\end{array}$ & 0.000 & 0.004 & . & 0.000 & 0.000 & 0.000 & 0.191 & 0.000 \\
\hline & Number & 52 & 52 & 52 & 52 & 52 & 52 & 52 & 52 \\
\hline \multirow{3}{*}{$\begin{array}{l}\text { Level } \\
\text { of } \\
\text { educat } \\
\text { ion }\end{array}$} & $\begin{array}{l}\text { Correlation } \\
\text { Coefficient }\end{array}$ & $0.331^{*}$ & 0.068 & $0.492^{* *}$ & 1.000 & $\underset{*}{0.612^{*}}$ & 0.224 & 0.175 & $\underset{*}{0.227}$ \\
\hline & $\begin{array}{l}\text { Sig.(2- } \\
\text { tailed) }\end{array}$ & 0.017 & 0.633 & 0.000 & . & 0.000 & 0.111 & 0.216 & 0.047 \\
\hline & Number & 52 & 52 & 52 & 52 & 52 & 52 & 52 & 52 \\
\hline \multirow{3}{*}{$\begin{array}{c}\text { Public } \\
\text { relatio } \\
\text { ns }\end{array}$} & $\begin{array}{l}\text { Correlation } \\
\text { Coefficient }\end{array}$ & $\underset{*}{0.858^{*}}$ & $0.459^{*}$ & $0.771^{* *}$ & $0.612^{* *}$ & 1.000 & $\underset{*}{0.646^{*}}$ & 0.262 & $\underset{* *}{0.778}$ \\
\hline & $\begin{array}{l}\text { Sig.(2- } \\
\text { tailed) }\end{array}$ & 0.000 & 0.001 & 0.000 & 0.000 & . & 0.000 & 0.061 & 0.000 \\
\hline & Number & 52 & 52 & 52 & 52 & 52 & 52 & 52 & 52 \\
\hline \multirow{3}{*}{$\begin{array}{l}\text { Advert } \\
\text { iseme } \\
\text { nt }\end{array}$} & $\begin{array}{l}\text { Correlation } \\
\text { Coefficient }\end{array}$ & $0.817^{*}$ & $\underset{*}{0.790^{*}}$ & $0.737^{* *}$ & 0.224 & $\underset{*}{0.646^{*}}$ & 1.000 & 0.252 & 0.857 \\
\hline & $\begin{array}{l}\text { Sig.(2- } \\
\text { tailed) }\end{array}$ & 0.000 & 0.000 & 0.000 & 0.111 & 0.000 & . & 0.072 & 0.000 \\
\hline & Number & 52 & 52 & 52 & 52 & 52 & 52 & 52 & 52 \\
\hline \multirow{3}{*}{$\begin{array}{l}\text { Visitin } \\
\mathrm{g} \text { the } \\
\text { selecte } \\
\mathrm{d} \\
\text { region } \\
\mathrm{s}\end{array}$} & $\begin{array}{l}\text { Correlation } \\
\text { Coefficient }\end{array}$ & $0.300^{*}$ & $\underset{*}{0.408^{*}}$ & 0.184 & 0.175 & 0.262 & 0.252 & 1.000 & 0.217 \\
\hline & $\begin{array}{l}\text { Sig.(2- } \\
\text { tailed) }\end{array}$ & 0.031 & 0.003 & 0.191 & 0.216 & 0.061 & 0.072 & . & 0.122 \\
\hline & Number & 52 & 52 & 52 & 52 & 52 & 52 & 52 & 52 \\
\hline $\begin{array}{c}\text { Touris } \\
\mathrm{m}\end{array}$ & $\begin{array}{l}\text { Correlation } \\
\text { Coefficient }\end{array}$ & $0.914^{*}$ & $\underset{*}{0.692^{*}}$ & $0.772^{* *}$ & $0.227^{*}$ & $0.778^{*}$ & $\underset{*}{0.857^{*}}$ & 0.217 & 1.000 \\
\hline
\end{tabular}




\begin{tabular}{|c|c|c|c|c|c|c|c|c|c|}
\hline $\begin{array}{c}\text { Develo } \\
\text { pment }\end{array}$ & $\begin{array}{c}\text { Sig.(2- } \\
\text { tailed) }\end{array}$ & 0.000 & 0.000 & 0.000 & 0.047 & 0.000 & 0.000 & 0.122 &. \\
\cline { 2 - 9 } & Number & 52 & 52 & 52 & 52 & 52 & 52 & 52 & 52 \\
\hline
\end{tabular}

${ }^{* *}$. Correlation is significant at the 0.01 level (2-tailed).

* Correlation is significant at the 0.05 level (2-tailed).

Source: The studies on the gathered information from the questionnaires, 2013

Considering the obtained data and applying the non-parametric test of Spearman, it can be noticed that the obtained rate of correlation between training of tourism development is 0.91 , the reliability of which is $99 \%$ significant. Hence, we can say that managers hold that proper training has an influential effect on the development of tourism. The rate of correlation with the budget is 0.69 which is significant at $99 \%$ reliability; the rate of correlation with education is 0.27 which is $95 \%$ significant in reliability; the correlation rate with public relations is 0.77 which is $99 \%$ significant is reliability; the correlation rate with the advertisements on tourism is 0.85 which is $99 \%$ significant in reliability, and from the perspective of managers, there is no significant relationship between visiting the sample tourist areas and tourism development; so, generally, there is a significant relationship between the empowering of managers and tourism development.

\section{Conclusion}

It can be concluded that village managers are on the belief that their empowering is essential in the development of tourism and finally the intended hypothesis of the study is approved. There can't be seen any significant relationship between visiting the successful and sample tourist areas and tourism development; in order to eliminate the present deficiencies and obtain the ideal condition, there should be a significant relationship.

Village managements will have a better performance provided that there are some appropriate bureaucratic and organizational structures. In other words, granting government support, providing services and financial and office support can guarantee the survival of village managements.

Tourism development can help overcome plenty of problems and obstacles; the most important advantages of rural tourism are as follows:

- Economic boom, creating various ways of producing income and guaranteeing it

- Employment and job opportunities as the major income source and developing some side activities

- Preventing the youth from migrating, and the possibility of attracting people to the area

- Maintaining and improving public services

- Improvement and development of infra-structures

- Development of handicrafts and spreading cultural identity

- Promoting opportunities for social and cultural interactions

- Efficient preservation of both natural and man-made environments

- Better understanding of the priorities of rural societies and the capabilities by those engaged in programming and making and determining policies 


\section{Bibliography}

Abdollahian, Hamid, Shariati, Shima \& Shoushtrizadeh, Elham. (2006). Measuring rural management performance in Iran, with regard to the factors effective in management process in the villages of Iran, Humanities teachers quarterly, special edition: Managment

Alqanami, M.R. (1993). Rural poverty cricis: can participation eliminate it? (Trans.: Oktaee, Naser). Village and development, no.5

Badri, Sayd Ali; Qadiri Massoum, Mojtaba; Farhadi, Samet \& Eskandari, Hafiz. (2010). A comparative study of rural managements of Iran and China with the approach of governing. Village and development quarterly, year 14, no. 3

Bontron, Jean-Claude and Nadine Lasnier. (1997). Tourism: A Potential Source

of Rural Employment, in Rural Employment. An International Perspective, Ray D. Bollman and John M. Bryden eds. New York: CAB International: 427-446

Bourke, Lisa and A. E. Luloff. (1995). Leaders Perspectives on Rural Tourism:

Case studies in Pennsylvania. Journal of the Community Development Society, Vol.26, No 2: 224-239

Brass, Jane L. (1996). Community Tourism Assessment Handbook. Corvallis,

Oregon: Western Rural Development Center, Oregon State University. Web Site: http://extension.usu.edu/wrdc/ctah

Burr, Steven W. (1995). The Rural Action Class's Perceptions of Tourism and

its Potential for Economic Development: Case studies from Four Rural Pennsylvania Counties. General Technical Report, Report No. INT-323: 82-89

Ebrahimzadeh, Eesa; Kazemirad, Shamsollah \& eskandari Sani, Mohammad. (2011). Strategic programming of tourism development, focusing on religious tourism (A case study; Qom city). Human geography studies, no. 76.

Emadi, Mohammad Hssein \& Darban Astaneh, Alireza. (2004). Determining the outline and indices of permanent rural development in rural and wandering tribes regions of Iran, the board of scientific researches of Iran

Este'laji, Alireza. (2012). Studying the model of rural management in Iran, focusing on local management and rural managements' participation. Research and science Quarterly of the geography of Iran, $10^{\text {th }}$ year, no. 32

Henning, Steven A. (1996). Developing a Rural Tourism Marketing Strategy

Based on Visitor Profiles. Louisiana Agriculture, Vol.39, No 1: 8-9

Interior Ministry. (2003). Special edition of councils, the elite national conference on the second period of Islamic councils, vice presidency of council and social affairs

Javan, jafar \& Saqaee, Mehdi. (2004). The role of rural tourism in regional development, focusing on rural management. The Quarterly of geography and regional development, no. 2. P. 109-124

Jome'pour, Mahmood. (1999). The process of permanent development and the role of participation in management and maximum productivity of natural resources. Articles of the conference on natural resources, participation and development. Jungles and pasture organization of Iran, Tehran 
Jurowski, Claudia (1996). Tourism Means More than Money to the Host

Community. Parks and Recreations, Vol.31, No 9: 110-118

Kay, Daram. (1992). Coopration development: perspective of rural people's experiences, translated by research center and studying the rural issues of reconstruction organization, village and development, no. 4

Khabbazzadeh, Nasim. (2011). Studying rural management in Iran, focusing on the performance of Islamic Councils, The monthly of rural managements, year 7 , no.35

Khoushegir, Mohammad, (2003). Studying the factors effective in the performance of rural Islamic Councils of Savojbolaq city, M.A Thesis, Tehran university

Lee, John. (1999). Tourism and development in developing countries. ( translated by Abdoreza Rohnodin Eftekhari et al). Tehran: commerce press co

Mahdavi, Masoud \& Najafi Kani, Ali Akbar. (2005). Village Managements, A different experience in the management of villages in Iran, random sample of village managements in western Azarbayjan province. The quarterly of geographical research, year 37. No. 1

Malekan, Ahmad \& Karimi, Seyd Hadi. (2011). Studying Rural management in Iran, focusing on the role councils and village managements. Monthly research magazine on spreading village managements, no. 35

Mirzaeee, Rahmat. ( 2009). The effect of developing rural tourism on job opportunities in the region of Ormanat, Kermanshah. Journal of village and development, year 12 , no. 4

Mohammadzadeh Larijani, Fatima \& Qorbani, Sahar. (2011). Studying the structural challenges of rural management in Iran. The national conference on rural development

Motiee Langroudi, Seyd Hassan. (2003). Rural planning focusing on Iran.

Mashhad: Jahad Daneshgahi press, first edition

Motiee Langroudi, Seyd Hassan \& Nosrati, Mahereh. (2011). Studying the possibility of tourism development in rural areas from the perpective of tourists (Gorganroud district at Talesh city). Journal of geography and environmental programming, year 22 . No. 1

Motiee Langroudi, Seyd Hassan. (2003). Rural management and reconstruction, an experience on Europe and North America. Journal of science and research quarterly of geography and regional development, Ferdowsi university of Mashhad

Nemati, MOrteza \& Badri, Seyd Ali. (2007). Assessing the practical role of the new system of rural management, a comparative analysis of active rural managements in small and big villages, a case study: Golestan province. Journal of geographical researches, no. 59

Research vice presidency and jahad daneshgahi of Tehran Branch, (1999). Studying and analyzing the laws and regulations related to village managements and offering legal suggestions for the sake of eliminating the vague point, challenges and its legal deficiencies. Mashhad: Jahad Daneshgahi press

Rezvani, Mohammadreza. (2004). An introduction to rural development programming in Iran. Tehran: SAMT Press

Qaderi Massoum, Mojtaba \& Riahi, Vahid. (2004). Studying the fields and challenges 
of rural management in Iran. Journal of geographical research

Saeedi, Abbas \& et al. (1991). Analyzing the methods of rural categorization. The first report, vice presidency of rural reconstruction at housing organization of the Islamic republic

Shamaee, Ali \& Mousavand, Jafar. (2011). Categorizing the cities of Isfahan province regarding the tourism infrastructure, using the models of TOPSIS and AHP,city and regional studies and researches, year 3 , no. 10

Taleb, Mehdi. (1997). Rural management in Iran, Tehran university

Taqavi, Ramin. (2006). Tourism in Kohkiloyeh and its role in development. A thesis for MA in sociology in Tehran University.

The Municipality organization of north khorassan province, (2013)

Vadiee, Kazem. (1969). An introduction to knowing villages in Iran. Tehran: Dehkhoda press

Vice Presidency of rural affairs. (1999). The performance of Iran's rural affairs vice Presidency. Tehran: The organization of Municipalities and village managements of Iran

Weaver, Glenn (1986). Tourism Development: A Potential for Economic Growth, in New Dimensions in Rural Policy: Building Upon our Heritage, Subcommittee on Agriculture and Transportation of the Joint Economic Committee. US. Congress: 440444

Woods, Mike D. (1992). The Tourism/Rural Economic Development Link. Blueprints for Economic Development Cooperative Extension Service, Oklahama State University, Vol.2, No 2: 2. 